\title{
SUBJECTIVE THEORIES AND MAIN PROBLEMS OF \\ PRESCHOOL TEACHER WORKING WITH GIFTED CHILD
}

\section{[SUBJEKTIVNE TEORIJE IN TEŽAVE VZGOJITELJA PRI DELU \\ Z NADARJENIM OTROKOM]}

\author{
Mojca Kukanja Gabrijelcic
}

\section{doi: 10.18355/PG.2016.5.1.86-100}

\begin{abstract}
In this paper, main problems regarding preschool teacher's subjective theories, problems and professional development in working with gifted children are presented. The results of the empirical research show the following problems: preschool teachers are inadequately informed about the issues concerning identifying and working with gifted young children; they tend to have low self-competence in identifying personal characteristics of gifted children and in the appropriate use of teaching strategies when working with gifted children; they stress the necessity for further education and professional training in the field of gifted children education. In addition to various possibilities of further education and inservice training, there are some issues that should be arranged on the national level, e. g.: empowering preschool teachers; providing teaching materials, teaching aids and special - didactic recommendations; shorter training workshops and others.
\end{abstract}

\section{Key words}

gifted children, preschool teacher, professional qualification, subjective theories

\section{Povzetek}

V prispevku predstavljamo nekatera ključna teoretična izhodišča s področja subjektivnih teorij, težav in profesionalnega razvoja vzgojitelja pri odkrivanju in delu z nadarjenimi otroki. Rezultati raziskave kažejo na: neustrezno informiranost vzgojiteljev na področju prepoznavanja in dela $\mathrm{z}$ nadarjenimi otroki; slabšo samooceno usposobljenosti učiteljev na področju poznavanja osebnostnih značilnosti nadarjenih ter ustrezne uporabe didaktičnih strategij pri delu $\mathrm{z}$ njimi; težave na področju osiromašenosti didaktičnih pripomočkov, dodatnega učnega gradiva, specialno-didaktičnih priporočil idr. Na področju stališč in čustev v odnosu do nadarjenih otrok izpostavljamo vzgojiteljeve kognicije, ki so $\mathrm{v}$ veliki meri pozitivno naravnane. V sklepih prispevka predstavljamo možne predloge in izboljšave ter opozorimo na nekatere možne sistemske rešitve za delo $\mathrm{z}$ nadarjenimi v prihodnje. Predvsem v smislu dodatnega izobraževanja in spopolnjevanja na nacionalnem nivoju; bogatega učnega gradiva, učil, učnih pripomočkov in specialno-didaktičnih priporočil; krajših izobraževanj, delavnic idr. 


\section{Ključne beside}

nadarjeni otroci, vzgojitelj, strokovna (ne)usposobljenost, težave, subjektivne teorije

\section{Uvod}

Vzgojitelji so dnevno izpostavljeni novim izzivom in zahtevam, med katerimi prednjačijo predvsem usposobljenost za delo z različnimi otroki (različne sposobnosti, posebne potrebe, multikulturne razlike); usposobljenost za refleksijo, raziskovanje in evalvacijo lastnega dela; odprtost za spreminjanje; timsko delo; večja mobilnost, inovatorstvo; skrb osebni in profesionalni razvoj; vzgojitelj kot del razvijajoče (učeče) se organizacije itd. (Day, 1999; Goodson, 2003; Persson, 2006).

Kako bo uresničen koncept predšolske vzgoje na podlagi novih izzivov in zahtev, je v veliki meri odvisno tudi od subjektivnih ali osebnih pojmovanj vzgojiteljev o otroku, vzgoji, zgodnjem učenju ter nadaljnjem profesionalnem razvoju. Kakovostno delo vzgojiteljev se namreč izkazuje tudi na področju koherentnega razvoja stališč vzgojiteljev in načel kurikuluma ter zavzemanja za demokratičen (pravičen) koncept predšolske vzgoje. Zatorej bi morali vzgojitelji $\mathrm{v}$ okviru neprekinjenega profesionalnega razvoja pridobiti znanja, ki bi omogočala odzivanje na nove izzive sodobnega pedagoškega dela, med katerimi je tudi delo z nadarjenimi otroki (Brookfield, 2005; Goodson, 2003; Persson, 2006).

$\mathrm{V}$ nadaljevanju zato predstavljamo nekatere subjektivne teorije vzgojiteljev ter ključne težave $\mathrm{s}$ katerimi se soočajo pri delu $\mathrm{z}$ nadarjenimi otroki $\mathrm{v}$ slovenskih javnih vrtcih.

\section{Subjektivne vs. etnoteorije vzgojitelja nadarjenega otroka}

strokovni literaturi obstajajo različni modeli in klasifikacije subjektivnih teorij o učenju in poučevanju tako šolskih kot tudi predšolskih otrok. Slednji izhajajo iz kognitivnih in afektivnih elementov, praktičnih ali laičnih teorij, ki (ne)posredno vplivajo na vzgojiteljevo delovanje (Sternberg in Davidson, 1986; Polak, 1996; Pintrich in Schunk, 2002; Batistic Zorec, 2003; Gomez Lopez, 2005). Termin etnoteorija/e oz. sistem/i kulturno posredovanih vrednot se v sodobni literaturi uporabljajo, ko govorimo o kulturni pogojenosti različnosti osebnih teorij (Harkness in Super, 1996), vendar ga ne smemo v celoti enačiti s terminom subjektivna teorija. Pri etnoteoriji gre namreč za skupek prepričanj, stališč in razlag neprofesionalnih vzgojiteljev in drugih laikov o otrokovi naravi in vzgoji, osnovan na vrednotah in vzgojnih praksah določenega kulturnega prostora. Potemtakem subjektivnih pojmovanj vzgojiteljic predšolskih otrok v celoti ne moremo enačiti $\mathrm{z}$ etnoteorijami, saj so vzgojiteljice strokovno izobražene in usposobljene za svoje delo, predvsem pa gre pri slednjih za kombinacijo implicitnih kot tudi eksplicitnih prepričanj.

B. Zorec (2003) opredeljuje subjektivne teorije vzgojiteljev kot eksplicitno izražena stališča, vrednote in razlage o vzgoji, kot tudi implicitne predpostavke, ki pa so nemalokrat v nasprotju z eksplicitnimi. Subjektivne (implicitne teorije) so osebne ideje, stališča, predaktivne in interaktivne 
odločitve, pripisovanja, pričakovanja in prepričanja o nekem pojavu, ki lahko odločujoče vplivajo na vzgojno-izobraževalno delo vzgojitelja oz. učitelja nadarjenega otroka (Gomez Lopez, 2005; Pintrich in Schunk, 2002; Sternberg in Davidson, 1986). A. Miljak (1993: 318) prav tako navaja, da implicitna (subjektivna) pedagogika, ki zajema vzgojiteljeva pričakovanja in predvidevanja o možnostih učenja in razvoja otrok, izrazito vpliva na učenje, razvoj, vzgojo in izobraževanje le-teh. Vsa zgoraj našteta prepričanja in stališča torej pomembno vplivajo na učiteljevo oz. vzgojiteljevo vedenje $\mathrm{v}$ predaktivnih (priprava) in interaktivnih (poučevanjskih) situacijah.

Problem nastane, ko govorimo o slabši usposobljenosti ali celo neusposobljenosti vzgojiteljev na področju odkrivanja in (pre)poznavanja značilnosti (potencialno) nadarjenih otrok. Vzgojitelji, ki se ukvarjajo z odkrivanjem in poučevanjem nadarjenih otrok ter na tem področju niso ustrezno strokovno usposobljeni, lahko s skupkom kognicij (ter nadaljnje kombinacijo etnoteorij in subjektivnih teorij, stališč in prepričanj), onemogočajo ustrezen razvoj otrokovih potreb, interesov in potencialov (Geak in Gross 2008; Szymanski in Shaff 2013: 20).

Prepoznavanje kognitivnih in afektivnih značilnosti/potreb je v primeru pomanjkanja ustreznega znanja vzgojiteljev podvrženo zgolj njihovim implicitnim (pogosto zmotnim) prepričanjem, stališčem in manifestacijam, ki jih imajo o tovrstni skupini otrok (Geak in Gross 2008; Szymanski in Shaff 2013: 20). Tako tudi Pegnato in Birch (1959, in Dobnik 1998) v svoji raziskavi poudarjata, da vzgojitelji/učitelji niso dovolj usposobljeni za odkrivanje in delo z nadarjenimi otroki, saj jih v postopku identifikacije kar precej izpustijo, medtem ko nadarjenost pripišejo nenadarjenim otrokom/učencem, najpogosteje bolj konformističnim.

Izhajamo iz predpostavke, da subjektivne teorije o učenju in poučevanju nadarjenih otrok temeljijo predvsem na vzgojiteljevem (ne)poznavanju lastnega procesa učenja in poučevanja - vezanega na prepoznavanje miselnih in drugih dejavnosti nadarjenih, njihovih nadpovprečnih sposobnosti, potreb in značilnosti na čustveno-socialnem področju. Profesionalni razvoj vzgojiteljev ter pridobivanje pedagoških izkušenj je pomemben iz vidika osebnostne in poklicne rasti, zato $\mathrm{v}$ nadaljevanju izpostavljamo nujnost dodatnega strokovnega izobraževanja/spopolnjevanja, saj slednji krepi področje vzgojiteljeve/učiteljeve samorefleksije in samoocenjevanja o lastnem delu in napredku.

\section{Znanja željni (ne)usposobljeni vzgojitelji}

$\mathrm{V}$ povezavi $\mathrm{s}$ stopnjo profesionalne usposobljenosti in področjem nadarjenosti, izpostavljamo skrb vzbujajoče raziskave, ki opozarjajo na perečo problematiko slabše usposobljenosti ali celo neusposobljenosti vzgojiteljev in učiteljev na področju odkrivanja in (pre)poznavanja značilnosti nadarjenih učencev ter nadaljnjega dela z njimi (Ferbezer, 2002; Hodge in Kemp, 2008; Kukanja, 2006; Kukanja Gabrijelcic, Cotar Konrad, 2014; Pfeiffer in Petscher, 2008; Pfeiffer in Jarosewich, 2003; Renzulli et. al., 2009). Raziskave potrjujejo izjemne potrebe nadarjenih učencev (Feldhusen in Kolloff, 1986; Van Tasel Baska, 2003), ki so lahko 
optimalno realizirane le $\mathrm{z}$ ustrezno usposobljenimi vzgojitelji/učitelji. Strokovna usposobljenost le-teh pa je na podlagi nekaterih raziskav pomembno povezana s pozitivnimi stališči in naravnanostjo do dela $\mathrm{z}$ nadarjenimi otroki (Hansen in Feldhusen, 1994; Megay-Nespoli, 2001).

Richert (1985, v Ferbezer in Kukanja, 2008) navaja, da med poglavitne probleme $\mathrm{z}$ običajnimi identifikacijskimi praksami sodi napačno razumevanje ali pomanjkljiva uporaba široke definicije nadarjenosti. Podobno ugotavljata tudi Kukanja Gabrijelcic in Cotar Konrad (2013), ki s predstavitvijo večplastnega problema, psihološke interdisciplinarne terminološke neenotnosti izrazov učna uspešnost, talentiranost in nadarjenost, raznovrstne terminološke izraze umestita tudi v slovenski raziskovalni prostor. ${ }^{19}$ Podobne težave imajo vzgojitelji pri (pre)poznavanju nadarjenosti mlajših otrok (Chitwood, 1986; Kukanja Gabrijelcic, Cotar Konrad, 2015; Porter, 2006; Primozic, 2013; Roedell e tal., 1980). Porter (2005) in Lee (2000) navajata skrb vzbujajoči raziskavi, kjer vzgojitelji pričajo o tem, da v 25-ih oz. 30-ih letih poučevanja niso (pre)poznali nobenega nadarjenega otroka.

Za zagotavljanje ustrezne učne in druge izkušnje nadarjenih morajo imeti vzgojitelji/učitelji nadarjenih otrok (Kukanja Gabrijelcic, 2014): (i) znanje in vrednotenje izvora ter narave sposobnosti nadarjenih otrok/učencev; (ii) znanje in razumevanje kognitivnih, socialnih in emocionalnih značilnosti, potreb in morebitnih specifičnih težav, s katerimi se srečujejo nadarjeni otroci/učenci; (iii) znanje, uporabo in dostop do naprednih vsebin, informacij in idej; (iv) sposobnost razvijanja diferenciranih učnih načrtov za delo $\mathrm{z}$ edinstvenimi intelektualnimi in čustvenimi potrebami in interesi nadarjenih otrok/učencev; (v) zmožnost za ustvarjanje varnega in spodbudnega okolja, $\mathrm{v}$ katerem lahko nadarjeni in talentirani izrazijo svojo edinstvenost.

Strokovno usposobljeni vzgojitelji oz. učitelji za delo z nadarjenimi otroki so $\mathrm{v}$ primerjavi s kolegi, ki se na tem področju niso dodatno strokovno spopolnjevali, izkazali:

(i) boljše pedagoške spretnosti ter uporabo različnih didaktičnih strategij pri poučevanju;

(ii) boljše sposobnosti (pre)poznavanja nadarjenih in njihovih potreb; pozitivnejši odnos do nadarjenih;

19 Avtorici ugotavljata, da se terminološke opredelitve visoke učne uspešnosti, nadpovprečnih zmogljivosti in sposobnosti posameznika, ki se izkazujejo v obliki visokih učnih dosežkov, koherentno povezujejo s terminom nadarjenost. Nekateri avtorji naštete termine celo uporabljajo kot sinonim (Van Tassel-Baska, Little, 2003). Njuna spoznanja kažejo na pomanjkljivo definicijo nadarjenosti in predvsem talentiranosti v slovenskem prostoru ter izmenljivo uporabo in interpretacijo pojmov $\mathrm{v}$ povezavi z učno uspešnostjo. Slednje bi bilo potrebno konceptualizirati in prilagoditi našemu okolju, saj je ustrezna definicija nadarjenosti tudi temelj nadaljnje priprave zakonodajnih in programskih izhodišč.

Slavonic Pedagogical Studies Journal, ISSN 1339-8660, Volume 5 Issue 1, February 2016 
(iv) nadarjeni so pri takih vzgojiteljih/učiteljih hitreje napredovali in dosegali boljše učne dosežke;

(v) vzgojitelji/učitelji so postavljali več divergentnih vprašanj, spodbujali kritično in ustvarjalno mišljenje (Geake in Gross, 2008; Hansen in Feldhusen, 1994; Silverman, 2013; Reis et al., 1998; Rizza in Morison, 2003; Westberg et al., 1993) .

V slovenskem prostoru dodatnih raziskav, ki bi slednje potrdile (še) nimamo, vendar pa tuja, empirično podkrepljena praksa kaže na visoko pomembnost vzgojiteljeve/učiteljeve usposobljenosti pri celostnem delu z nadarjenimi (Hansen, Feldhusen, 1994; Parker, Karnes, 1991; Tomlinson et. al 1994). Pedagoški delavci $\mathrm{z}$ opravljenim usposabljanjem so namreč izkazali veliko večje didaktično-metodične spretnosti pri delu z nadarjenimi, ki so se izkazovale predvsem na akademskem in osebnostnem področju tovrstne skupine otrok (Wright, Horn, Senders, 1997). Tako tudi Ferbežer (2016) ugotavlja, da je relativno povečano učinkovitost vzgojiteljevih opazovalnih ocen mogoče doseči $s$ sistematičnim strokovnim usposabljanjem bodisi $\mathrm{v}$ dodiplomskih, pogosteje pa $\mathrm{v}$ podiplomskih programih in programih stalnega strokovnega izobraževanja.

Če zgoraj navedeno primerjamo s področjem vzgojiteljevih subjektivnih teorij, ugotavljamo, da temelji kontinuirano izgrajevanje vzgojiteljeve profesionalne identitete na samorefleksiji in implementaciji novih spoznanj s področja nadarjenosti, torej na kombinaciji znanstvenega in razumnega, kar pa je tudi pogoj za uspešno

\section{Problem in namen raziskave}

Osnovni namen študije je bila analiza področja profesionalnega razvoja in stalnega strokovnega izobraževanja/spopolnjevanja ter subjektivnih teorij (prepričanj, mnenj, stališč, čustev) vzgojiteljev na področju odkrivanja in dela $\mathrm{z}$ nadarjenimi otroki $\mathrm{v}$ slovenskih javnih vrtcih. Izhajamo namreč iz premise, da je v sodobnem pedagoškem polju skrb za profesionalno rast in kakovostno izobraževanje temeljnega pomena, če želimo doseči pomembnejše premike na področju vzgoje in izobraževanja nadarjenih otrok/učencev. Neustrezno (pre)poznavanje značilnosti, razumevanje nadarjenih otrok in pomanjkljiva usposobljenost pedagoških delavcev lahko posledično privedeta tudi do neustrezne ali pomanjkljive uporabe učnih metod, oblik in dejavnosti pri delu s tovrstno skupino učencev.

V okviru tega smo oblikovali tri širše raziskovalne sklope, in sicer:

(i) stopnja informiranosti in subjektivne teorije pedagoških delavcev na področju odkrivanja in dela $\mathrm{z}$ nadarjenimi otroki; (ii) samoocena pedagoških delavcev o strokovni (ne)usposobljenosti na področju odkrivanja in dela $\mathrm{z}$ nadarjenimi otroki; (iii) analiza težav pri delu $\mathrm{z}$ nadarjenimi otroki in interesov oz. potreb pedagoških delavcev za nadaljnje strokovno izobraževanje in spopolnjevanju. 


\section{Metoda}

$\mathrm{V}$ raziskavi je sodelovalo 156 vzgojiteljic, ${ }^{20} \mathrm{~s}$ povprečno starostjo 40 let $(\mathrm{M}=39.80, \mathrm{~S}=9,75)$ in $\mathrm{v}$ večini visokošolsko stopnjo izobrazbe $(76,0$ \%). Za namene omenjene študije smo oblikovali vprašalnik o odkrivanju in delu s potencialno nadarjenimi otroki, s skupno dvanajstimi vprašanji (vprašanji odprtega tipa in vprašanji zaprtega tipa, kjer so udeleženci raziskave na štiri ali pet-stopenjski lestvici po posameznih trditvah ocenjevali svojo splošno in specifično usposobljenost za delo z nadarjenimi otroki).

\section{Pripomočki}

Pri raziskavi smo uporabili kvantitativno neeksperimentalno empirično metodo pedagoškega raziskovanja. Obdelavo podatkov smo opravili s statističnim programom SPSS, ki vključuje frekvenčno distribucijo spremenljivk in Pearsonov $\chi^{2}$-test.

\section{Rezultati diskusijo}

V nadaljevanju predstavljamo rezultate po temeljnih sklopih raziskave.

Stopnja informiranosti in subjektivne teorije pedagoških delavcev na področju odkrivanja in dela s potencialno nadarjenimi otroki

Pedagoški delavci (v nadaljevanju vzgojitelji) poročajo o tem, da so izjemno slabo seznanjeni s kompleksnostjo problematike odkrivanja in dela z nadarjenimi otroki (Tabela 1). Vidimo namreč, da 3,20\% vzgojiteljev meni, da je s konkretno tematiko seznanjena, 39,10\% udeležencev raziskave o svoji informiranosti dvomita, medtem, ko jih 57,69 \% ocenjuje, da niso pridobili nikakršnega psihološkega in pedagoškega znanja o prepoznavanju nadarjenosti pri predšolskih otrocih in delu $\mathrm{z}$ njimi $\mathrm{V}$ programih obveznega izobraževanja za vzgojitelje na srednji, višji in/ali visoki stopnji.

Tabela 1 Samoocena pedagoškega delavca o seznanjenosti s tematiko nadarjenosti

\begin{tabular}{ccccc}
\hline seznanjenost $(\mathrm{N}=156)$ & $\mathrm{F}(\%)$ & $\chi^{2}$ & $\mathrm{df}$ & $\mathrm{p}$ \\
\hline $\mathrm{Da}$ & $5(3,20 \%)$ & & & \\
ne vem & $61(39,10 \%)$ & 71,80 & 2 & $<0,01$ \\
$\mathrm{Ne}$ & $90(57,69 \%)$ & & & \\
\hline
\end{tabular}

Na vprašanje o tem, ali lahko prepoznamo znake otrokove (potencialne) nadarjenosti že v predšolskem obdobju je 152 (97, 43 \%) vzgojiteljev odgovorili pritrdilno (ne $\left.-2,57 \% ; \chi^{2}(\mathrm{df}=1)=140,41, \mathrm{p}<0,0001\right)$.

V nadaljevanju so vzgojitelji odgovarjali na vprašanje, ali menijo, da prepoznajo značilnosti nadarjenih otrok. Pri tem jih je je $98(62,82 \%)$

\footnotetext{
${ }^{20}$ Ker so $\mathrm{v}$ raziskavi sodelovale zgolj vzgojiteljice, v nadaljevanju uporabljamo Ženski slovnični spol.
}

Slavonic Pedagogical Studies Journal, ISSN 1339-8660, Volume 5 Issue 1, February 2016 
odgovorilo z pritrdilno, ne(pre)poznavanje značilnosti je potrdilo 32 vzgojiteljev (20,51 \%), odgovora pa ni podalo $26(16,66 \%)$ vzgojiteljic. Za preverjanje zgornjih odgovorov smo ugotavljali razlike med skupinami o prepoznavanju značilnosti nadarjenih na predšolski stopnji ter stopnjo izobrazbe in število let delovne dobe vzgojiteljic. Rezultati so pokazali, da med spremenljivkama ni statistično pomembne povezanosti.

Sledilo je vprašanje o tem, ali imajo vzgojitelji v oddelku več nadarjenih otrok. Da je v oddelku več nadarjenih otrok meni 42 (26,9 \%) vzgojiteljic; da $\mathrm{v}$ oddelku nima več nadarjenih otrok je odgovorilo $89(57,05 \%)$ vzgojiteljic; na vprašanje pa ni podalo odgovora $25(16,02 \%)$ vzgojiteljic. Ugotavljamo, da je manj kot tretjina anketiranih vzgojiteljic prepoznala nadarjene otroke $\mathrm{v}$ svojem oddelku. Tiste vzgojiteljice, ki so navedle, da imajo več nadarjenih otrok $\mathrm{v}$ oddelku, $\mathrm{v}$ poprečju navajajo 3,25 nadarjenih otrok na oddelek. Najmanjše število nadarjenih otrok na oddelek (min) je 1 , največje $(\max )$ pa 15. Najpogosteje so navedle, da imajo v oddelku 2 nadarjena otroka (M). Raziskave (Ferbezer, 2005) so pokazale da vzgojitelji, brez pedagoško-psihološkega svetovanja o značilnostih nadarjenih otrok niso realno ocenjevali, saj so precenjevali sposobnosti nadarjenih otrok. Prav tako je Kaufman [1973] ugotovil, da so ti vzgojitelji identificirali višji odstotek zmerno in skrajno visoko nadarjenih predšolskih otrok (v Ferbezer, 2005: 171).

Subjektivne teorije vzgojiteljev pri delu s (potencialno) nadarjenimi otroki $\mathrm{V}$ študiji so vzgojitelji s pomočjo nedokončanih stavkov izrazili svoja stališča in prepričanja o nadarjenih otrocih, o delu $\mathrm{z}$ njimi ter svojem počutju pri delu z nadarjenimi. Pri ugotavljanju stališč, prepričanj in čustev vzgojiteljev do nadarjenih otrok in vzgojno-izobraževalnega dela z njimi, smo izpostavili trditve, ki so jih vzgojitelji ustrezno dopolnili. Vsebinsko ponavljajoče se oz. podobne odgovore smo združevali v sorodne kategorije. Ugotovitve kažejo, da učitelji $\mathrm{v}$ največji meri označujejo nadarjenega učenca kot:

i) drugačnega, posebneža, otroka s posebnimi potrebami (15,2\%);

ii) bogastvo, dar družbe, izziv (12,5\%);

iii) bistrega, inteligentnega, nadpovprečnega (10,8 \%) ter

iv) izstopajočega na določenem učno-storilnostnem področju $(11,15 \%)\left(\chi^{2}=65,38 ; \mathrm{g}=7 ; \mathrm{p}<0,001\right)$.

Stališča učiteljev do nadarjenih učencev so bila $\mathrm{v}$ veliki meri pozitivna, med negativnimi so te označili predvsem kot nagajive, nemirne in moteče $(1,3 \%)$, obenem pa je zanimivo dejstvo, da več kot tretjina od vseh vprašanih pedagoških delavcev na to vprašanje ni odgovorila. Čeprav prevladuje mnenje, da so nadarjeni »drugačni«, bi bilo smiselno raziskati $\mathrm{v}$ kakšnem pomenu si učitelji tako »drugačnost« tudi razlagajo. Odnos do drugačnosti je namreč ključni pobudnik razvoja družbene strpnosti in predstavlja inkluzivno kulturo sobivanja $\mathrm{v}$ globalni družbi in $\mathrm{v}$ šoli.

Glede na pristranskost vzgojiteljevih stališč smo v nadaljevanju ugotavljali ali predsodek, ki ga ima vzgojitelj kot izoblikovano predstavo o nadarjenem otroku, vpliva na nadaljnje vzgojno-izobraževalno delo $z$ njim. Ugotavljamo, da so stališča, ki jih učitelji udejanjajo pri delu z nadarjenimi, precej ambivalentna (glej Tabela 2). Največkrat se je pojavil odgovor, da je 
delo naporno in zahtevno, vendar hkrati polno izzivov, poučno, neprecenljivo ipd. (40,3 \%), sledi pa pozitivno stališče, kjer so učitelji delo $\mathrm{z}$ nadarjenim učencem ocenili kot delo, ki jim je $\mathrm{v}$ veselje in zabavo $(14,7 \%)$. Ugotavljamo, da so razlike med skupinami statistično pomembne $\left(\chi^{2}(\mathrm{df}=6)=95,462, \mathrm{p}<0,0001\right)$.

Tabela 2 Stališča vzgojiteljev o delu $s$ (potencialno) nadarjenim otrokom

\begin{tabular}{|c|c|c|c|}
\hline \multicolumn{2}{|c|}{ Delo z nadarjenim otrokom je ... } & $f$ & $f(\%)$ \\
\hline \multirow{4}{*}{  } & Izziv & 22 & $14,1 \%$ \\
\hline & Zanimivo in pestro, bogato & 17 & $10,8 \%$ \\
\hline & $\mathrm{V}$ veselje in zabavo & 23 & $14,7 \%$ \\
\hline & Čudovita, bogata izkušnja & 10 & $6,41 \%$ \\
\hline \multirow{5}{*}{ 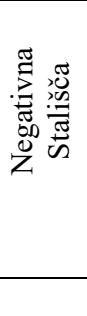 } & Naporno in zahtevno* & 63 & $40,3 \%$ \\
\hline & Drugačno, nepredvidljivo & 13 & $8,3 \%$ \\
\hline & $\begin{array}{l}\text { *ambivalentno stališče učiteljev: hkrati } \\
\text { pomeni izziv, neprecenljivo, poučno, } \\
\text { aktivno, častno, razveseljujoče }\end{array}$ & & \\
\hline & Ni odgovoril & 8 & $5,12 \%$ \\
\hline & Skupaj & 156 & $100 \%$ \\
\hline
\end{tabular}

V nadaljevanju (Tabela 3) prikazujemo čustva, ki jih v vzgojiteljih sprožijo nadarjeni otroci, kjer ugotavljamo, da je delo z njimi v veliki večini $(30,7 \%)$ povezano s pozitivnimi čustvi (zadovoljstvo, energija, sreča), čeprav ne gre spregledati dejstva,da jih 25,6 \% navaja tudi negativna čustva (dvom, strah, nemoč, neznanje, zaskrbljenost).

Tabela 3 Čustva, ki jih pri delu s (potencialno) nadarjenim otrokom doživljajo vzgojitelji

\begin{tabular}{|c|c|c|c|c|}
\hline \multicolumn{3}{|c|}{ Nadarjenost v meni sproža naslednja čustva ... } & $\mathrm{f}$ & $f(\%)$ \\
\hline \multirow{3}{*}{ 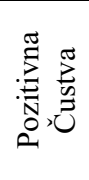 } & zadovoljstvo, veselje, srečo & & 48 & $30,7 \%$ \\
\hline & radovednost, energijo, zagon za & izziv & 22 & $14,1 \%$ \\
\hline & naklonjenost, & občudovanje, & 39 & $25,0 \%$ \\
\hline \multirow[t]{3}{*}{ 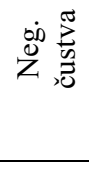 } & $\begin{array}{l}\text { Dvom*, strah, nemoč, jezo } \\
\text { *ambivalentnost }\end{array}$ & & 40 & $25,6 \%$ \\
\hline & Ni odgovoril & & 7 & $4,4 \%$ \\
\hline & Skupaj & & 156 & $100 \%$ \\
\hline
\end{tabular}

Slavonic Pedagogical Studies Journal, ISSN 1339-866o, Volume 5 Issue 1, February 2016 
Pri zadnjem sklopu odprtih vprašanj smo ugotavljali počutje vzgojiteljic pri delu z nadarjenimi otroki, kjer jih je največ izrazilo, da se počutijo dobro, srečno, izpopolnjeno (38,2 \%), med negativnimi občutki pa je prevladovala posameznikova nemoč, ki se pojavi kot posledica nekompetentnosti in strokovne neusposobljenosti za delo z nadarjenimi otroki $(12,3 \%) ; \chi^{2}(d f=7)$ $=261,20, p<0,0001$. Zato smo $\mathrm{v}$ nadaljevanju ugotavljali, kakšna je učiteljeva samoocena o strokovni usposobljenosti na področju odkrivanja in dela z nadarjenimi otroki.

ii) Samoocena vzgojiteljev o strokovni (ne)usposobljenosti na področju odkrivanja in dela z mlajšimi nadarjenimi otroki

Analiza je pokazala, da vzgojitelji najpogosteje svojo strokovno usposobljenost za delo $\mathrm{z}$ nadarjenimi na splošno ocenjujejo kot zadovoljivo $54,6 \%$, medtem, ko se jih $45,4 \%$ ocenjuje kot premalo usposobljene za poučevanje nadarjenih otrok. Nihče od vzgojiteljev pa se ni ocenil kot zelo dobro usposobljenega na področju dela z mlajšimi nadarjenimi otroki.

Podrobnejša analiza specifične usposobljenosti vzgojiteljev na različnih področjih poznavanja značilnosti in dela z nadarjenimi pokaže, da se slednji ocenjujejo kot najbolj (a še vedno zmerno) kompetentne predvsem na področju spodbujanja ustvarjalnosti (glej tabela 4), kot slabo usposobljene pa se ocenjujejo tako na področju (pre)poznavanja značilnosti nadarjenih kot tudi na področju (upo)rabe ustreznih diferenciranih didaktičnih strategij pri delu z njimi. Glede na povprečno oceno vzgojiteljev (zadovoljiva usposobljenost) bi bilo $\mathrm{v}$ prihodnosti smiselno opraviti longitudinalne raziskave s področja vzgojiteljeve strokovnosti, kompetenc, subjektivnih teorij ter njihovega neposrednega vpliva na vsestranski, optimalen razvoj nadarjenega otroka.

Tabela 4 Povezanost med specifičnimi področji usposobljenosti in pogostostjo profesionalnega ravnanja vzgojitelja pri delu $z$ nadarjenimi otroki

\begin{tabular}{|c|c|c|c|c|c|}
\hline \multirow{5}{*}{$\begin{array}{c}\text { Specifične } \\
\text { usposobljen } \\
\text { osti }\end{array}$} & \multirow{5}{*}{$\begin{array}{l}\text { značilno } \\
\text { sti nad. } \\
\text { did.strate } \\
\text { gije } \\
\text { ustvarjal } \\
\text { nost }\end{array}$} & \multicolumn{3}{|c|}{ Specifične usposobljenosti } & $\begin{array}{l}\text { profesionalno } \\
\text { ravnanje }\end{array}$ \\
\hline & & $\begin{array}{l}\text { značilno } \\
\text { sti nad. }\end{array}$ & $\begin{array}{c}\text { did.stra } \\
\text { tegije }\end{array}$ & $\begin{array}{l}\text { ustvarjaln } \\
\text { ost }\end{array}$ & \multirow{4}{*}{$\begin{array}{l}0,35 * * \\
0,43 * * \\
0,45 * *\end{array}$} \\
\hline & & & $0,82 * *$ & \multirow{3}{*}{$0,78 * *$} & \\
\hline & & & & & \\
\hline & & & & & \\
\hline \multicolumn{2}{|c|}{$\mathrm{N}$} & 156 & 156 & 156 & 156 \\
\hline \multicolumn{2}{|c|}{$M$} & 2,84 & 2,84 & 3,05 & 2,79 \\
\hline \multicolumn{2}{|c|}{$S D$} & 0,92 & 0,92 & 0,94 & 0,42 \\
\hline
\end{tabular}

Legenda: $* *$ razlika je statistično pomembna na nivoju $\mathrm{p}<0,01$ 
Sklepamo lahko, da se vzgojiteljeva strokovnost in občutek kompetentnosti na splošnem in specifičnem področju delovanja $\mathrm{z}$ nadarjenimi, krepi predvsem skozi kvalitetno stalno strokovno izpopolnjevanje. Zato smo v nadaljevanju preverjali ključne vrzeli oz. težave s katerimi se vzgojitelji najpogosteje soočajo pri svojem delu.

iii) Analiza ključnih težav vzgojiteljev na področju dela z nadarjenimi otroki

V zadnjem raziskovalnem vprašanju smo se osredotočili na ključne težave $\mathrm{s}$ katerimi se soočajo vzgojitelji pri delu $\mathrm{z}$ nadarjenimi otroki ter na potrebe in interese, ki jih imajo $\mathrm{v}$ zvezi $\mathrm{z}$ nadaljnjim izobraževanjem na tem področju. Analiza izpostavljenih težav, s katerimi se srečujejo vzgojitelji pri delu z nadarjenimi prikazuje (glej tabela 5), da slednji skorajda enotno poročajo o tem, da čutijo kot veliko težavo pomanjkanje znanja na področju (pre)poznavanja značilnosti nadarjenih otrok ter pomanjkanje posebnih didaktičnih pripomočkov, dodatnega učnega gradiva, specialno-didaktičnih priporočil idr. pri učnem delu z njimi.

Tabela 5 Analiza ključnih težav vzgojiteljev pri delu za nadarjenimi otroki

\begin{tabular}{|c|c|c|c|c|c|c|}
\hline & \multirow[b]{2}{*}{ težave } & \multicolumn{2}{|c|}{ Prisotnost težave } & \multirow[b]{2}{*}{$\chi^{2}$} & \multirow[b]{2}{*}{$\mathrm{df}$} & \multirow[b]{2}{*}{$\mathrm{p}$} \\
\hline & & $\mathrm{NE}$ & $\mathrm{DA}$ & & & \\
\hline 1. & $\begin{array}{l}\text { Pomanjkanje znanja na } \\
\text { področju poznavanja } \\
\text { značilnosti nadarjenih. }\end{array}$ & 44 & 112 & 29,64 & 1 & ,000 \\
\hline 2. & $\begin{array}{l}\text { Nezadostna } \\
\text { usposobljenost za delo } \\
\text { z nadarjenimi otroki. }\end{array}$ & 33 & 123 & 51,92 & 1 & 000 \\
\hline 3. & $\begin{array}{l}\text { Pomanjkanje posebnih } \\
\text { didaktičnih } \\
\text { pripomočkov. }\end{array}$ & 27 & 129 & 66,69 & 1 &, 000 \\
\hline 4. & $\begin{array}{l}\text { Pomanjkanje } \\
\text { dodatnega učnega } \\
\text { gradiva, specialno- } \\
\text { didaktičnih priporočil } \\
\text { in drugega za delo z } \\
\text { nadarjenimi. }\end{array}$ & 46 & 110 & 26,25 & 1 &, 000 \\
\hline 5. & $\begin{array}{l}\text { Slabše izdelan ali } \\
\text { predstavljen } \\
\text { individualiziran } \\
\text { program za } \\
\text { nadarjenega otroka. }\end{array}$ & 25 & 131 & 72,02 & 1 &, 000 \\
\hline & $\begin{array}{l}\text { Nezadostna podpora } \\
\text { drugih institucij, ki } \\
\text { zgolj nalagajo skrb za } \\
\text { delo z nadarjenimi } \\
\text { otroki. }\end{array}$ & 40 & 116 & 37,02 & 1 &, 000 \\
\hline
\end{tabular}

\section{Sklepi in usmeritve}

$\mathrm{V}$ prispevku smo predstavili nekaj aktualnih vprašanj s področja dela $\mathrm{z}$ nadarjenimi otroki na predšolski stopnji. Področje nadarjenih se ponekod, 
ne glede na nivo v vzgojno-izobraževalni vertikali, srečuje s podobnimi težavami (kot so npr. težave pri jasni opredelitvi pojmov in natančni rabi terminologije), drugod so težave vezane na specifične vzgojno-pedagoške okoliščine ter subjektivne teorije vzgojiteljev. Ugotavljamo, da se največje težave pojavljajo predvsem v sistemskih pomanjkljivostih: i) terminološki konceptualizaciji; ii) pomanjkljivi informiranosti in usposobljenosti vzgojiteljev na področju odkrivanja in dela $\mathrm{z}$ nadarjenimi otroki; iii) formalizaciji zakonodajnih in programskih izhodišč s področja nadarjenosti na predšolski stopnji.

Usmeritve se nanašajo predvsem na:

(i) zakonska izhodišča, ki bi jih morali normativno sistemizirati oz. strokovno formalizirati $\mathrm{s}$ Pravilnikom odkrivanja in dela $\mathrm{s}$ potencialno nadarjenimi otroki na predšolski stopnji ter Pravilnikom profesionalnega razvoja potrebnih kompetenc, ki naj bi jih imeli pedagoški delavci, ki delajo s tovrstno skupino otrok. Poleg tega predlagamo obogatitev Kurikuluma za vrtce $\mathrm{s}$ konkretnimi primeri dejavnosti za spodbujanje ter razvijanje visokih učnih potencialov otrok;

(ii) bogato učno gradivo, učila, učne pripomočke in specialnodidaktična priporočila, ki bi jih vzgojitelj lahko uporabil pri delu s specifično skupino otrok;

(iii) krajša oz. daljša izobraževanja za pedagoške delavce, ki bi svojo strokovnost izkazovali $\mathrm{z}$ nacionalnim certifikatom oz. ustreznim potrdilom o opravljenem izobraževanju oz. izpopolnjevanju.

Vzgojitelj lahko z oblikovanjem pozitivnega učnega okolja sodoloča učno identiteto nadarjenega otroka ter s krepitvijo telesnega in duševnega razvoja otrok omogoča izražanje vseh njegovih potencialov (Čotar Konrad in Kukanja Gabrijelčič, 2014; 2016). Menimo, da mora biti pri tem pozoren predvsem na nekatere bistvene učne momente:

(i) pri prepoznavanju nadarjenosti izkazuje vzgojitelj ustrezno širino, kjer vsakemu otroku zagotavlja možnosti za realizacijo njegovih potencialov in je pozoren na morebitno identifikacijo potencialno nadarjenega predšolskega otroka;

(ii) vzgojitelj, kot opazovalec otrokovega vedenja, skrbi za realizacijo obogatitvenega kurikuluma in vzpostavlja učno stimulativno okolje, dejavnosti in situacije, v katerih dela otrok sam, v paru ali skupini;

(iii) na osnovi sistematičnega in načrtnega opazovanja otrokovih interesov in močnih področij, pripravlja učno diferencirane in individualizirane dejavnosti, naloge, gradiva ipd.;

(iv) vzgojitelj dodatno načrtno spodbuja otrokovo ustvarjalnost pri likovnih, tehničnih, konstrukcijskih, oblikovalnih, gibalnih, plesnih, glasbenih in drugih dejavnostih;

(v) vzgojitelj na osnovi opazovanja in poznavanja specifičnega delovanja vsakega otroka spodbuja otrokov odnos do igre in dela, gradi na vztrajnosti in pozornosti, ohranja vedoželjnost, razvija interese, motorične in govorne sposobnosti, samoiniciativnost in socialne spretnosti ustrezne komunikacije $\mathrm{z}$ drugimi otroki. 
Pomemben element vzgojiteljevega profesionalnega razvoja so tudi subjektivne teorije, tj. stališča, vrednote ter prepričanja, ki se združujejo v njegovo osebno teorijo o pedagoškem delu. Bistvo profesionalnega razvoja pedagoških delavcev je ravno $\mathrm{v}$ tem, da se omenjene teorije oz. laični koncepti postopoma, longitudinalno spreminjajo in nadgrajujejo do optimalnega nivoja profesionalnosti. Glede na to, da na oblikovanje vzgojiteljevih/učiteljevih subjektivnih teorij o nadarjenosti vplivajo predvsem trije osnovni elementi oz. dejavniki: osebne izkušnje vzgojitelja, posredovano znanje in izkušnje ter učiteljeve vrednote, ne smemo zanemariti vpliva družbene in vrtčevske/šolske klime. Pri tem ugotavljamo, da je pedagoško delo $v$ našem vzgojno-izobraževalnem sistemu prepuščeno ustvarjalnosti, avtonomnosti in strokovnosti slehernega vzgojitelja/učitelja, da samostojno prilagodi in izvede učne aktivnosti, ki so primerne nadarjenim učencem. Ravno strokovna avtonomija in $\mathrm{z}$ njo povezani odgovornost ter stopnja samoodločanja, so bistvene značilnosti sodobnega vzgojitelja/učitelja. Zato je skrb za njihovo profesionalno rast in kakovostno izobraževanje temeljnega pomena, če želimo doseči pomembnejše premike na področju vzgoje in izobraževanja nadpovprečno sposobnih, nadarjenih učencev.

Navsezadnje, izhajamo iz premise, da samo socialno-čustveno zrel vzgojitelj lahko utre pot $h$ kakovostnejšemu poučevanju, saj so pri vzgojitelju kot tudi pri otrocih socialno-emocionalne spretnosti temeljno povezane s kognitivnimi. Temeljni pogoj za to ni samo dobra strokovna usposobljenost $\mathrm{v}$ metodah in tehnikah vzgojno-izobraževalnega dela, temveč bogate življenjske izkušnje, pozitivne moralne lastnosti, bogata pedagoška praksa, življenjska socialno-emocionalna zrelost ter uravnoteženost (Kukanja Gabrijelčič, 2010).

\section{Bibliographic references}

BROOKFIELD, S. 2005. Power of critical theory for adult learning and teaching. Berkdire, Great Britain: McGraw-Hill Education.

CHITWOOD, D. G. 1986. Guiding parents seeking testing. Roeper Review, 8(3), pp. 177-179.

DAY, C. 1999. Developing Teachers. The Challenges of Lifelong Learning. London: Falmer Press.

DOBNIK, B. 1998. Identifikacija nadarjenih učencev. In Pedagoška obzorja, 4, pp. 5-30.

FERBEZER, I. - KUKANJA, M. 2008. Svetovanje nadarjenim ucencem. Ljubljana: Zavod Republike Slovenije za solstvo.

FERBEZER, I. 2002. Celovitost nadarjenosti. Nova Gorica: Educa.

FERBEZER, I. 2016. Povezovanje identifikacije in edukacije mlajsih nadarjenih otrok. V: Zeljeznov Senicar, M. (ur.), Nadarjeni in talentirani predsolski otrok, pp. 40-50. Ljubljana: MIB d.o.o.

GABRIJELCIC, K. M. - KONRAD, C. S. 2016. Izzivi in tezave na podrocju odkrivanja in dela $\mathrm{z}$ mlajsimi nadarjenimi otroki. In Zeljeznov 
Senicar, M. (ur.). Nadarjen in talentiran predsolski otrok, pp. 28-40. Ljubljana: MIB.

GABRIJELCIC, K. M. - KONRAD, C. S. 2013. Ucno uspesen, nadarjen ali talentiran: terminoloske vrzeli s podrocja nadarjenosti. in Pedagoska obzorja, 28 (3/4), pp. 129-143.

GABRIJELCIC, K. M. - KONRAD, C. S. 2015. Strokovna usposobljenost pedagoskh delavcev in stalisca do nadarjenih ucencev. In Edukacijske vede v postmodernizmu. Germany: Shaker Verlag.

GABRIJELCIC, K. M. 2010. Socialna inteligenca ucitelja nadarjenega ucenca. In Socialne in custvene potrebe nadarjenih in talentiranih. II. mednarodna znanstvena konferenca, (ur.) Zeljeznov Senicar, M., pp. 404417. Ljubljana: MIB.

GABRIJELCIC, K. M. 2014. Drzava, ucitelj in delo z nadarjenimi ucenci: med poslanstvom in odgovornostjo. In Revija za elementarno izobrazevanje, 7 (1), pp. 83-97.

GABRIJELCIC, K.. M. 2015. Profesionalni razvoj uciteljev in tezave pri delu z nadarjenimi ucenci. In Pedagoska obzorja, 30, 1, pp. 112-127.

GEAKE, J. G. - GROSS, M. U. M. 2008. Teachers' negative affect toward academically gifted students: An evolutionary psychological study. In Gifted Child Quarterly, 52(3), pp. 217-231.

GOODSON, I. 2003. Professional knowledge, professional lives: studies in education and change. Philadelphia: Open University Press.

HANSEN, B. - FELDHUSEN, J. F. 1994. Comparison of Trained and Untrained Teachers of Gifted Students. In Gifted child Quarterly, vol. 38, no. 3, pp. 115-12.

HARKNES, S. - SUPER, C. M. 1996. Introduction. V S. Harkenss in C. M. Super (ur.), Parents' cultural belief systems: the origins, expressions and consequences. New York: Guilford Press.

HODGE, K. A. - KEMP, C. R. 2006. Recognition of giftedness in the early years of school: Perspectives of teachers, parents, and children. In Journal for the Education of the Gifted, 30 (2), pp. 164-204.

KUKANJA, M. 2006. Delo z nadarjenimi učenci na osnovnih solah mestne obcine Koper. Solsko svetovalno delo, letnik XI, st. 3-4, pp. 50-60.

LEE, L. 2000. Teachers' conceptions of giftedness: What does it mean for young girls and boys? In The Australasian Journal of Gifted Education, 9 (2), pp. 24-32.

LOPEZ. G. F. 2005. Filosofía institucional, teorias implicitas de los docentes y practica educativa. In Revista Latinoamericana de Estudios Educativos, XXXV(1-2), pp. 35-88.

MEGAY - NESPOLI, K. 2001. Beliefs and attitudes of novice teachers regarding instruction of academically talented learners. In Roeper Review, 23, pp. 178-182.

MILJAK, A. 1993. Realni in razvojni kurikulum. In Educa, 5, pp. 315-322. PARKER, J. - KARNES, F. 1991. Graduate degree programs and resource centers in gifted education: An update and analysis. In Gifted Child Quarterly, 35, pp. 43-48. 
PERSSON, M. 2006. A vision of European teaching and learning: perspectives on the new role of the teacher. Karlstad: Learning Teacher Network.

PFEIFFER, S. I. - JAROSEWICH, T. 2003. Gifted Rating Scales. The Psychological Corporation: San Antonio, Texas.

PFEIFFER, S. - PETSCHER, Y. 2008. Identifying young gifted children using the Gifted Rating Scales - preschool/kindergarten form. In Gifted Child Quarterly, 52 (1), pp. 19-29.

PINTRICH, P. R. - SCHUNK, D. H. 2002. Motivation in education: Theory, research, and applications. Upper Saddle River, N.J.: Merrill.

POLAK, A. 1996. Subjektivne teorije uciteljev in studentov pedagoskih smeri glede na smer izobrazbe in pedagoske izkusnje. Magistrsko delo. Ljubljana: Filozofska fakulteta, Oddelek za psihologijo.

PORTER, L. 2005. Gifted young children: A guide for teachers and parents. Sydney, Australia: Allen \& Unwin.

PRIMOZIC, M. 2013. Odkrivanje nadarjenih v predsolskem obdobju in delo z njimi. Magistrska naloga. UP: Pedagoska fakulteta.

REIS, S. M. - WESTBERG, K. L. - KULIKOWICH, J. M. - PURCELL, J. H. 1998. Curriculum compacting and achievement test scores: What does the research say? In Gifted Child Quarterly, 42, pp. 123-129.

RENZULLI, J. S. - SIEGLE, D. - REIS, S. M. - GAVIN, M. K. - REED, R E. S. 2009. An investigation of the reliability and factor structure of four new Scales for Rating the Behavioral Characteristics of Superior Students. In Journal of Advanced Academics 22 (1), pp. 84-108.

RIZZA, M. G., IN MORRISON, W. F. 2003. Uncovering stereotypes and identifying characteristics of gifted students and students with emotional/behavioral disabilities. In Roeper Review, 25 (2), pp. 73-77.

ROEDELL, W. C. - JACKSON, N. E. IN ROBINSON, H. B. 1980. Gifted young children. New York, NY: Teachers College, Columbia University.

SILVERMAN, S. 2013. How are Gifted teachers different than Other Teachers? Denver: Gifted Development Center. Available online: http:/www.gifteddevelopment.com. (Pridobljeno 30. aprila 2014).

STERNBERG, R. J. - DAVIDSON, J. E. 1986. Conceptions of giftedness: A map of the terrain. In R. J. Sternberg \& J. E. Davidson (Eds.), Conceptions of Giftedness, pp. 3-18. New York: Cambridge University Press.

SZYMANSKI, T. - SHAFF, T. 2013. Teacher Perspectives Regarding Gifted Diverse Students. Gifted Children, 6, 1. Available online: http://docs.lib.purdue.edu/giftedchildren/vol6/iss1/1.

TOMLINSON, C. - TOMCHIN, E. - CALLAHAN, C. - ADAMS, C. PIZZAT-TIMI, P. - CUNNINGHAM, C. - MOORE, B. - LUTZ, L. ROBERTSON, C. - EISS, N. - LANDRUM, M. - HUNSAKER, S. IMBEAU, M. 1994. Practices of preservice teachers related to gifted and other academically diverse learners. In Gifted Child Quarterly, 38, pp. 106114.

VAN TASSEL - BASKA, J. - LITTLE A. C. 2003. Content-Based Curriculum for High Ability Learners. Texas: Prufrock Press, Inc.

Slavonic Pedagogical Studies Journal, ISSN 1339-866o, Volume 5 Issue 1, February 2016 
VAN TASSEL - BASKA, J. 2003. Content-Based Curriculum for High Ability Learners: An introduction. In Van Tassel - Baska, J., Little A. C. (ur.). Content-Based Curriculum for High Ability Learners. Texas: Prufrock Press, Inc., pp. 1-23.

WESTBERG, K. L. - ARCHAMBAULT, F. X. JR. - DOBYNS, S. M. SALVIN, T. J. 1993. An observational study of instructional and curricular practices used with gifted and talented students in regular classrooms. Storrs: University of Connecticut, the National Research Center on the Gifted and Talented.

WRIGHT, S. - HORN, S. P. - SANDERS, W. L. 1997. Teachers and classroom context effects on student achievement: Implications for teacher evaluation. In Journal of Personnel Evaluation in education, 11, pp. 57-67. ZOREC, B. M. 2003. Razvojna psihologija in vzgoja v vrtcih. Ljubljana: Inštitut za psihologijo osebnosti.

Doc. dr. Mojca Kukanja Gabrijelčič

University of Primorska

Faculty of Education

Cankarjeva 5, 6000 Koper

Slovenia

mojca.k.gabrijelcic@pef.upr.si 